Article

\title{
Solution-Processed Efficient Nanocrystal Solar Cells Based on CdTe and CdS Nanocrystals
}

\author{
Songwei Liu ${ }^{1}$, Weigeng Liu ${ }^{1}$, Jingxuan Heng ${ }^{1}$, Wenfeng Zhou ${ }^{1}$, Yanru Chen ${ }^{1}$, Shiya Wen ${ }^{1}$, \\ Donghuan Qin ${ }^{1, *}$ (D), Lintao Hou ${ }^{2, *}$, Dan Wang ${ }^{1,3}$ and Hui Xu ${ }^{4}$ \\ 1 School of Materials Science and Engineering, South China University of Technology, \\ Guangzhou 510640, China; majestyv@sina.com (S.L.); victorlwg@sina.com (W.L.); \\ hengjingxuan@163.com (J.H.); 18826075592@163.com (W.Z.); caro_ccyr@163.com (Y.C.); \\ a740176840@163.com (S.W.); wangdan@scut.edu.cn (D.W.) \\ 2 Guangdong Provincial Key Laboratory of Optical Fiber Sensing and Communications, Guangzhou Key \\ Laboratory of Vacuum Coating Technologies and New Energy Materials, Siyuan Laboratory, \\ Department of Physics, Jinan University, Guangzhou 510632, China \\ 3 Institute of Polymer Optoelectronic Materials \& Devices, State Key Laboratory of Luminescent Materials \& Devices, \\ South China University of Technology, Guangzhou 510640, China \\ 4 College of Petrochemical Technology, Lanzhou University of Technology, Lanzhou 730050, China; \\ xuhui@lut.cn \\ * Correspondence: qindh@scut.edu.cn (D.Q.); thlt@jnu.edu.cn (L.H.); \\ Tel.: +86-20-8711-4346 (D.Q.); +86-20-8522-4386 (L.H.)
}

Received: 15 November 2017; Accepted: 4 January 2018; Published: 5 January 2018

\begin{abstract}
Solution-processed CdTe nanocrystals solar cells have attracted much attention due to their low cost, low material consumption, and potential for roll-to-roll production. Among all kinds of semiconductor materials, CdS exhibits the lowest lattice mismatch with $\mathrm{CdTe}$, which permits high junction quality and high device performance. In this study, high quality CdS nanocrystals were prepared by a non-injection technique with tetraethylthiuram disufide and 2,2'-dithiobisbenzothiazole as the stabilizers. Based on the CdTe and CdS nanocrystals, devices with the architecture of $\mathrm{ITO} / \mathrm{ZnO} / \mathrm{CdS} / \mathrm{CdTe} / \mathrm{MoO}_{x} / \mathrm{Au}$ were fabricated successfully by a solution process under ambient condition. The effects of annealing conditions, film thickness, and detailed device structure on the $\mathrm{CdTe} / \mathrm{CdS}$ nanocrystal solar cells were investigated and discussed in detail. We demonstrate that high junction quality can be obtained by using CdS nanocrystal thin film compared to traditional CdS film via chemical bath deposition (CBD). The best device had short circuit current density $\left(J_{\mathrm{sc}}\right)$, open circuit voltage $\left(V_{\mathrm{oc}}\right)$ and fill factor (FF) of $17.26 \mathrm{~mA} / \mathrm{cm}^{2}, 0.56 \mathrm{~V}$, and $52.84 \%$, respectively, resulting in a power conversion efficiency (PCE) of $5.14 \%$, which is significantly higher than that reported using CBD CdS as the window layer. This work provides important suggestions for the further improvement of efficiency in CdTe nanocrystal solar cells.
\end{abstract}

Keywords: nanocrystal; CdTe; CdS; solar cells; solution processed

\section{Introduction}

Thin film solar cells based on solution-processed semiconductor nanocrystals (NCs) have many advantages such as wide spectra response from ultraviolet to infrared [1], low cost, environmental-friendly process, and potential development to roll-to-roll large area production [2-6]. With the progress of nanomaterials fabrication techniques, various high quality semiconductor NCs have been synthesized and investigated. However, only a few of these materials such as $\mathrm{PbS}[7,8]$, PbSe [9], CdTe [10-12], and CuInSe 2 (CIS) [13,14], have been successfully exploited for photovoltaic application. Among these materials, CdTe may be one of the most studied NCs due to their reasonable 
bandgap ( $1.45 \mathrm{eV})$ for light harvesting. Efficient CdTe thin film solar cells are always fabricated with a hetero-junction configuration, that is, CdTe works as the donor and CdS [15,16], ZnSe [17], ZnS [18], as well as $\mathrm{ZnO}$ [19] serve as the acceptors. Among all kinds of electron acceptor materials, CdS has the smallest lattice mismatch with CdTe and high quality hetero-junction is expected for a solar cell with a CdTe/CdS conformation. Recently, efficiency up to $22.1 \%$ [20] and an open circuit voltage up to $1 \mathrm{~V}$ [21] were demonstrated by using a $\mathrm{CdTe} / \mathrm{CdS}$ hetero-junction configuration. However, solution-processed CdTe NC solar cells have only recently been studied, and their properties are not fully understood. The use of solution-processed NC solar cells can reduce the consumption of materials, simplify the preparation process, and thus obtain a low-cost commercial product. In 2005, Gur et al. [22] first reported the solution-processed CdTe/CdSe NC hetero-junction solar cells with a power conversion efficiency (PCE) of $\sim 3 \%$. Subsequently, this device architecture was further investigated by optimizing the device processing technology and device structure (using an inverted structure such as ITO/ZnO/CdSe/CdTe/ $\mathrm{Au}$ instead of the normal structure of ITO/CdTe/CdSe/ $\mathrm{Al}$ ). Devices with improved $V_{\text {oc }}(\sim 0.65 \mathrm{~V})$ and PCE $(\sim 6 \%)$ have been recently demonstrated [23-26]. Since both the donor and acceptor materials have similar morphology, structure and size, good hetero-junction quality is expected. Another relatively successful CdTe NC solar cell was developed based on the $\mathrm{CdTe} / \mathrm{ZnO}$ hetero-junction with a normal structure of ITO/CdTe/ZnO/Al. By using a layer-by-layer sintering technique to eliminate inner stress, Mulvaney et al. $[27,28]$ demonstrated a PCE of $\sim 7.0 \%$ for $\mathrm{CdTe} / \mathrm{ZnO}$ solar cells with a structure of ITO/CdTe/ZnO/Al. However, as CdTe exhibits high electron affinity and high resistivity [29], the contact between ITO and CdTe is not ohmic, which restricts the further promotion of efficiency. Building on these results, it was found that light or current treatment can reduce the interface barrier between ITO and CdTe, which dramatically improves the open circuit voltage and filling factor of the devices, resulting in more than $10 \%$ energy conversion efficiency [30]. Unfortunately, although a device with a high conversion efficiency was achieved using this method, the stability of the device was insufficient, as the efficiency will be decreased by more than $20 \%$ over several days of storage after light/current treatment [31]. The inverted structure $(\mathrm{ITO} / \mathrm{ZnO} / \mathrm{CdTe} / \mathrm{Au})$ can solve the problem of the interface barrier, but the treatment of CdTe NC film with $\mathrm{CdCl}_{2}$ will pollute the $\mathrm{ZnO}$ and generate more interface defects, resulting in a low efficiency $(\sim 2 \%)$ [24]. So far, $\mathrm{CdSe}[23,24], \mathrm{ZnO}[32]$ and $\mathrm{TiO}_{2}[33,34]$ have been successfully applied to CdTe NC solar cells as acceptor materials, but few reports have focused on CdTe/CdS NC solar cells. Recently, we used a chemical bath deposition (CBD) method to prepare CdS films, and a CdTe NC solar cell with an inverted structure was prepared by depositing CdTe NC on the CdS film. By optimizing the heat treatment conditions, 3.73\% PCE was obtained with structure of $\mathrm{ITO} / \mathrm{ZnO} / \mathrm{CdS} / \mathrm{CdTe} / \mathrm{MoO}_{x} / \mathrm{Ag}$ [35]. Crisp et al. fabricated CdTe/CdS NC solar cells by using CBD-CdS (with device configuration of FTO/ $\mathrm{SnO}_{2} / \mathrm{CdS} / \mathrm{CdTe} / \mathrm{ZnTe} / \mathrm{Ti}$ ) [36] and sputtered CdS (with device configuration of FTO/CdS/CdTe/ZnTe/metal contact) [37] as the electron acceptors, PCEs of as high as $6.66 \%$ and $5.2 \%$ are obtained in two cases, which are the highest values ever reported for CBD-CdS/CdTe and sputtered CdS/CdTe NC solar cells respectively. It must be pointed out that the grain size of CBD-CdS ( several micrometers) is much larger than that of CdTe NC ( 100 nm after chemical/heat-treatment), which may cause large interface defects, leading to large leakage currents and low $V_{\text {oc }} / \mathrm{FF}$. Inspired by the success of CdTe/CdSe all inorganic donor/acceptor NC solar cells, we hypothesized that the substitution of CdS NC for CBD-CdS would improve the quality of the hetero-junction due to the similar morphology and size of CdS and CdTe NCs, resulting in improved overall device performance. Here, high quality CdS NCs were synthesized by a non-injection method with tetraethylthiuram disufide and 2,2'-dithiobisbenzothiazole as nucleation initiators. Devices with the configuration of ITO/ZnO/CdS $/ \mathrm{CdTe} / \mathrm{MoO}_{x} / \mathrm{Au}$ were prepared using a layer-by-layer sintering process. The heat treatment temperature, film thickness, and device architecture have significant effects on the performance of the solar cells. We demonstrate here that it is possible to improve both the $V_{\mathrm{oc}}$ and the $\mathrm{FF}$ of $\mathrm{CdTe} / \mathrm{CdS} \mathrm{NC}$ solar cells by optimizing the film treatment processing, which modified the interface properties of $\mathrm{CdTe} / \mathrm{CdS}$ that govern the charge separation and recombination processes. 
At an optimized heat treatment temperature of $380^{\circ} \mathrm{C}$, we obtained the best device, with $V_{\mathrm{oc}}=0.56 \mathrm{~V}$, $J_{\mathrm{sc}}=17.26 \mathrm{~mA} / \mathrm{cm}^{2}, \mathrm{FF}=52.84 \%$, and $\mathrm{PCE}=5.14 \%$. This $\mathrm{PCE}$ value is increased by $35 \%$ compared to a device with $\mathrm{CBD}-\mathrm{CdS}$ as the window layer prepared under the same conditions.

\section{Experiment Procedure}

\subsection{Materials}

Cadmium acetate dihydrate $\left(\left(\mathrm{CH}_{3} \mathrm{COO}\right)_{2} \mathrm{Cd} \cdot 2 \mathrm{H}_{2} \mathrm{O}\right), 2,2^{\prime}$-dithiobisbenzothiazole, tetraethylthiuram disufide, myristic acid $\left(\mathrm{C}_{14} \mathrm{H}_{28} \mathrm{O}_{2}\right)$, tri- $n$-octylphosphine, tellurium powder, and octadecene (ODE) were purchased from Aladdin, Shanghai, China. All other chemicals and solvents were used as received.

\subsection{Synthesis Methods}

$\mathrm{ZnO}$ precursor and CdTe NCs were prepared by the method reported in previous works $[23,24]$. CdS NCs were fabricated by a non-injection method (CdS NC is formed gradually during the reaction) using tetraethylthiuram disufide and $2,2^{\prime}$-dithiobisbenzothiazole as nucleation initiators [38]. A typical synthetic procedure is as follows: $2 \mathrm{mmol}(533.04 \mathrm{mg})$ cadmium acetate dihydrate, $4 \mathrm{mmol}(913.48 \mathrm{mg}$ ) myristic acid, $0.125 \mathrm{mmol}$ tetraethylthiuram disufide $(37.07 \mathrm{mg}), 0.375 \mathrm{mmol}$ 2,2'-dithiobisbenzothiazole (124.68 mg), $1 \mathrm{mmol}$ sulfur (32 mg), and $50 \mathrm{~mL}$ ODE were added into a three-necked flask. The mixture was heated to $120{ }^{\circ} \mathrm{C}$ under $\mathrm{N}_{2}$ flow and then maintained at this temperature for $2 \mathrm{~h}$ to ensure all the chemical substances were dissolved. Then, the mixture was heated to $240{ }^{\circ} \mathrm{C}$ at a rate of $10^{\circ} \mathrm{C} / \mathrm{min}$. Needle tip aliquots were removed for UV-Vis (UV-5100B, Shanghai Metash Instrument Co., Ltd., Shanghai, China) measurements to monitor the formation of CdS NCs. When the targeted size of NCs was achieved, the reaction mixture was allowed to cool down to room temperature. To purify the NCs, the final product was washed with acetone three times and then separated by centrifugation. The product was then dispersed and washed with methanol/toluene and separated by centrifugation twice to remove excess precursors and other impurities. The total yield of the CdS NCs prepared by this method was $90 \%$. Finally, the CdS NCs were refluxed in pyridine for $12 \mathrm{~h}$ at $80^{\circ} \mathrm{C}$ to make ligands exchange and remove most of carboxyl ligands. After that, the product was washed with $n$-hexane and separated by centrifugation. After drying by $\mathrm{N}_{2}$ flow, the CdS NCs was dispersed into pyridine at a concentration of $30 \mathrm{mg} / \mathrm{mL}$.

\subsection{Device Fabrication}

The solar cells with the ITO/ZnO/CdS $/ \mathrm{CdTe} / \mathrm{MoO}_{3} / \mathrm{Au}$ structure were prepared by a layer-by-layer solution process, as shown in Figure 1. First, the $\mathrm{Zn}^{2+}$ precursor was deposited on ITO substrate and annealed at $400{ }^{\circ} \mathrm{C}$ for $10 \mathrm{~min}$ to eliminate any organic solvent and allow the formation of a thin film of $\mathrm{ZnO}$ with a thickness of $\sim 40 \mathrm{~nm}$. Several drops of CdS NCs solution were then applied to the ITO/ZnO substrate and spin-casted at $3000 \mathrm{rpm}$ for $20 \mathrm{~s}$. The substrate was first annealed at $150{ }^{\circ} \mathrm{C}$ for $10 \mathrm{~min}$ and then transferred to another hot plate and annealed at $360^{\circ} \mathrm{C}$ for $40 \mathrm{~s}$. The thickness of CdS NCs with a single layer was about $15-20 \mathrm{~nm}$. To obtain a device with a thicker CdS NC film, additional layers of CdS NCs were deposited on the substrate sequentially and treated with the same conditions. In this way, five layers of CdTe NCs were deposited on the ITO/ZnO/CdS substrate by a process similar to that described previously [23]. Finally, the substrate was placed on a hot plate at $300-400{ }^{\circ} \mathrm{C}$ for $30 \mathrm{~min}$ to activate the junction of CdTe/CdS. From the cross-section Scanning Electron Microscope (SEM, Nova NanoSEM 430, Thermo Fisher Scientific, Eindhoven, The Netherlands) images, the thickness of CdTe NC film was around $400 \mathrm{~nm}$. The $\mathrm{MoO}_{x}(\sim 8 \mathrm{~nm})$ and $\mathrm{Au}(\sim 80 \mathrm{~nm})$ back contact were deposited in sequence via thermal evaporation through a shadow mask with an active area of $0.16 \mathrm{~cm}^{2}$. 


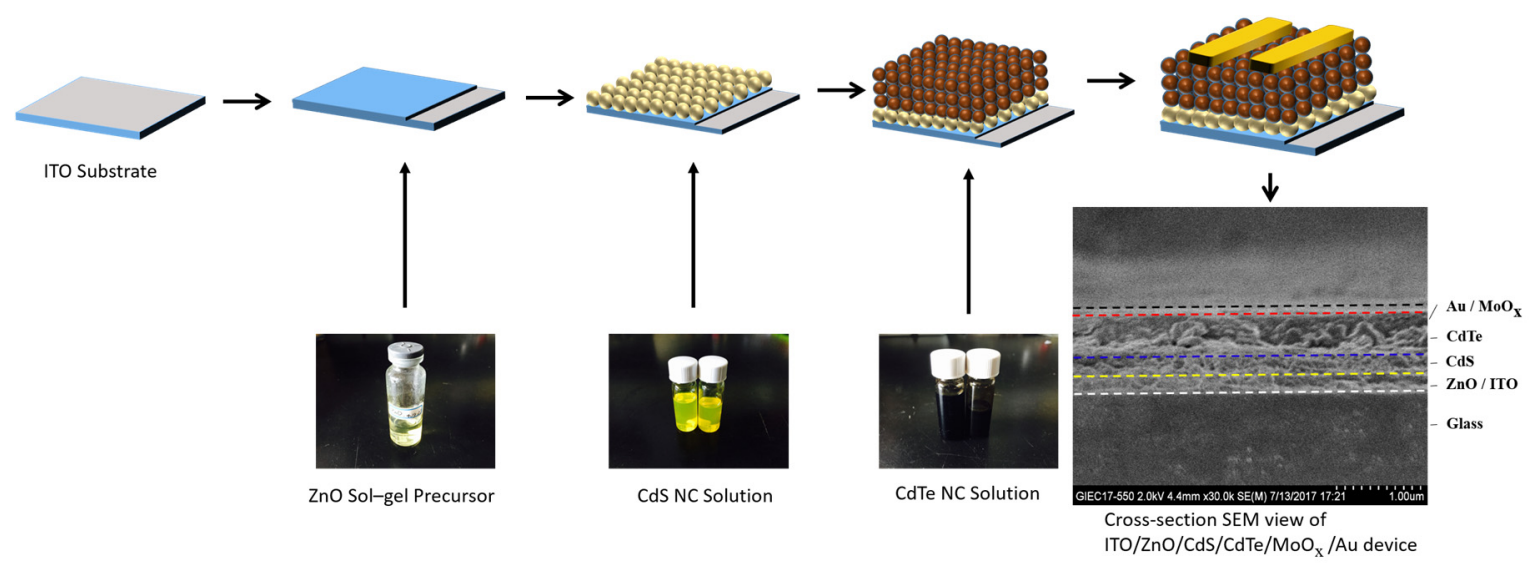

Figure 1. A Schematic of the device fabrication process.

\section{Results and Discussion}

Although the synthesis of CdS NCs has been reported previously [39-42], it remains a goal to obtain CdS NCs with well-controlled size, high yield, and good dispersion in organic solvents for applications in photoelectronic devices. Compared with cadmium ions, the activity of sulfur is very low. The addition of the initiator ensures the activity of the two materials, leading to high-quality NCs. To investigate the growth kinetics of CdS NCs, we monitored the UV-Vis spectra for different growth times $(1 \mathrm{~min}-2 \mathrm{~h})$ after the reaction temperature reached $240{ }^{\circ} \mathrm{C}$. As shown in Figure 2a, the absorption peak of CdS NC for a short growth time of $1 \mathrm{~min}$ is at $376 \mathrm{~nm}$, but the peak is at $380 \mathrm{~nm}$ for a growth time of $1 \mathrm{~h}$, this feature at $380 \mathrm{~nm}$ corresponds to CdS NCs less than $3 \mathrm{~nm}$ in diameter [43]. Note that there is an increase in absorption at longer wavelengths (400-500 nm) after $\sim 10 \mathrm{~min}$ of growth time, which may imply that some NCs grow to a larger size. Therefore, a little red-shift is observed for feature peaks and increased absorption at long wavelengths is also observed, which is different from that observed for CdS NC fabrication [38]. It is evident that the peaks are sharp and narrow in the half-band width when the reaction time is below $30 \mathrm{~min}$, which implies a good size distribution for CdS NC. In contrast, flattening of the UV peak is observed when the reaction time was increased to 1-2 h, which implies NCs with large size distribution. We hypothesize that the nucleation speed is very fast as the quantity of $\mathrm{Cd}$ precursor and nucleation initiators $\left(I_{1}\right.$ and $\left.I_{2}\right)$ are ten times higher than the amounts used previously [38]. The nucleation and growth stages are not separated in this process, so there should be no significant size changes for most of the NCs while some large NCs will be formed with growth time. The transmission spectrum of the CdS NC thin film (ITO/ZnO/CdS) with different thicknesses is shown in Figure 2b. The NC thin-films blocked the light with a wavelength shorter than $500 \mathrm{~nm}$ and showed high transparency for wavelengths $>500 \mathrm{~nm}$. The transmission decrease in the wavelength below $\sim 500 \mathrm{~nm}$ with increased thickness of CdS NC was due to the bandgap ( $2.43 \mathrm{eV}$ for CdS) absorption, while there were few changes for wavelength $>500 \mathrm{~nm}$.

According to the results shown in Figure 2a, a reaction time of $30 \mathrm{~min}$ was required to ensure a uniform size distribution of CdS NC. The morphology and structure were further characterized by TEM, high-resolution transmission electron microscopy (HRTEM, JEM-2100F, Hitachi, Tokyo, Japan), and X-ray Diffraction (XRD, X'pert Pro M, Philips, Amsterdam, The Netherlands). As shown in Figure 3a, the CdS NC showed dot-shaped morphology with an average diameter of $13.2 \mathrm{~nm}$ (Figure $3 \mathrm{~b}$ ) and exhibited aggregation, which was much larger than that predicted from Figure 2a. We hypothesized that the NCs were not well-dispersed in toluene, therefore high aggregation NCs were observed in this case. The CdS NC powder sample for XRD measurement was prepared by refluxing CdS NC in pyridine for $12 \mathrm{~h}$ and separated by centrifugation. Then it was dried under vacuum drying oven at $120^{\circ} \mathrm{C}$ for 1 day. Characteristic diffraction patterns with peaks at about $25.1^{\circ}, 35.3^{\circ}, 41.8^{\circ}, 45.7^{\circ}$ and $49.6^{\circ}$ were identified from the XRD pattern (Figure 3d), corresponding to the (111), (220), (311), (400), and (331) planes of 
the CdS zinc blend crystal phase. The crystallinity and structural integrity of the CdS NC were further characterized by HRTEM (Figure 3c). The spacing between the two planes was $0.223 \mathrm{~nm}$, corresponding to the (220) plane of the zinc blend phase of the CdS NCs.
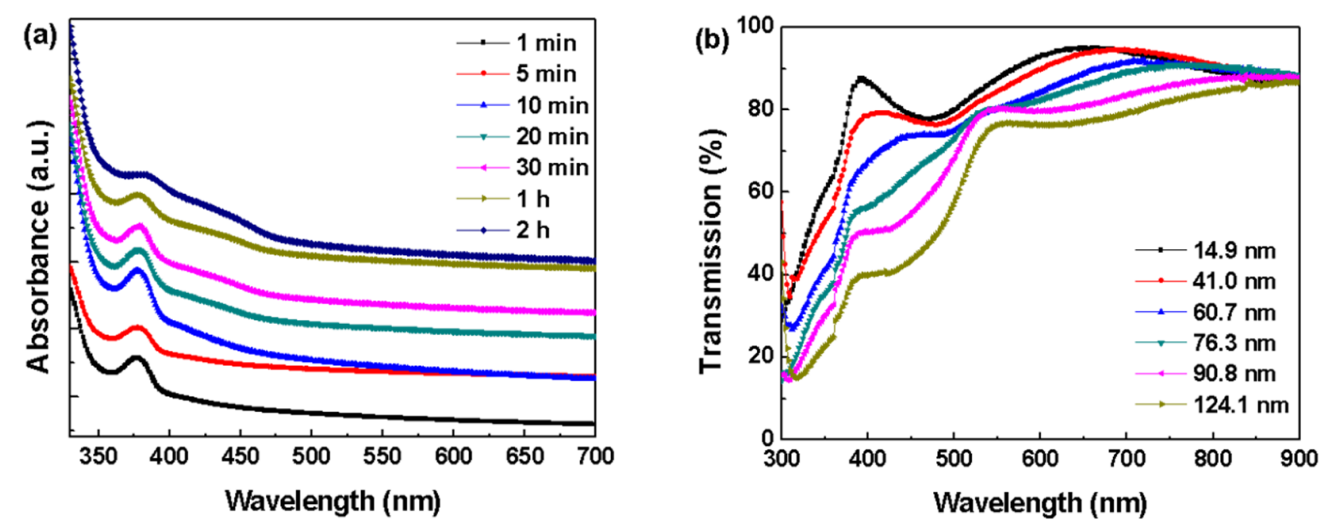

Figure 2. (a) UV absorbance of CdS NCs with different growth time; (b) Transmission spectra of $\mathrm{ITO} / \mathrm{ZnO} / \mathrm{CdS}$ with different CdS thickness.
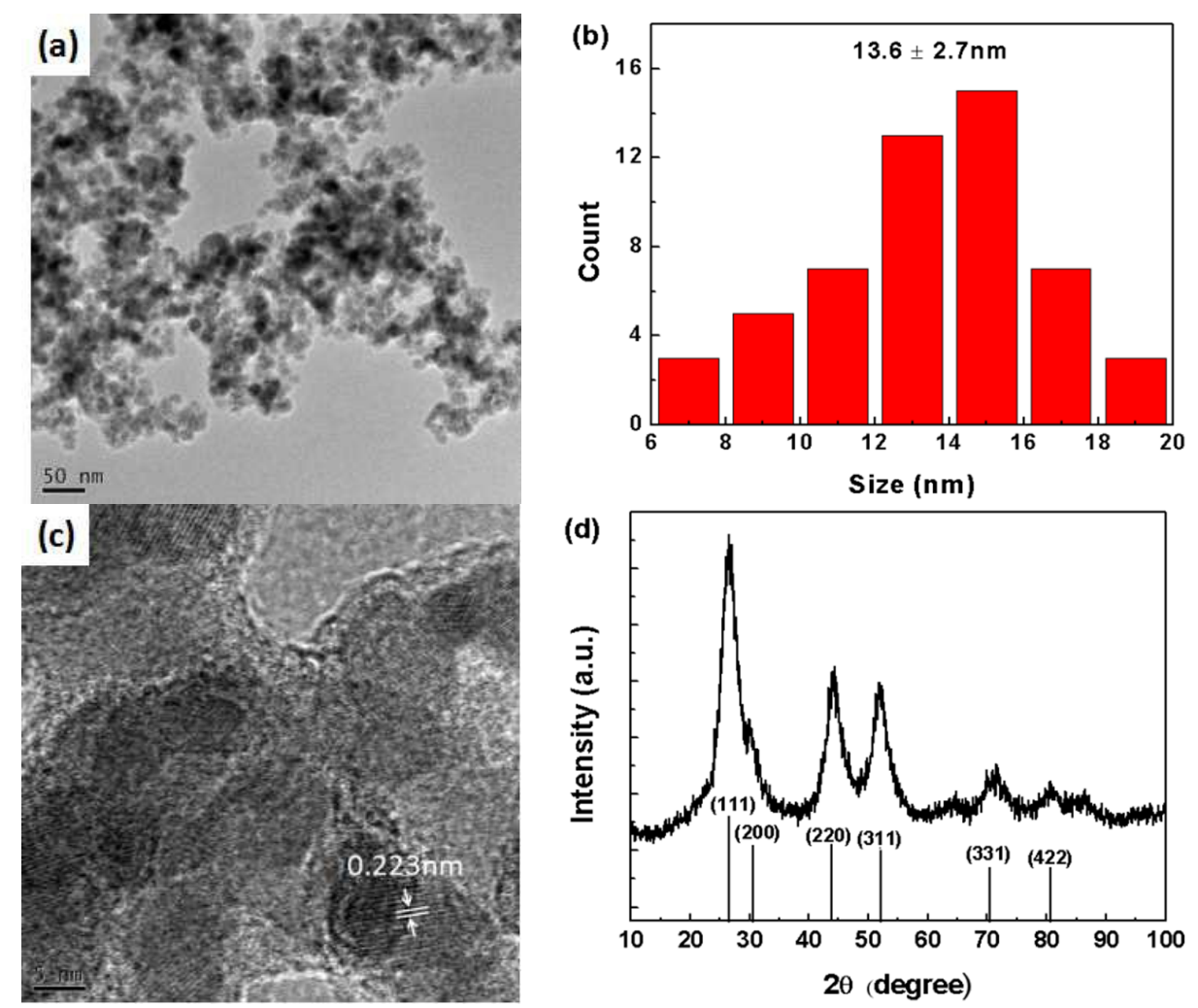

Figure 3. (a) TEM image, (b) particle size distribution, and (c) HRTEM image of the CdS NCs; (d) the XRD pattern of the CdS NCs.

Now we pay attention to the performance of NC solar cells. CdTe-CdS all inorganic NC solar cells were fabricated using a simple layer-by-layer sintering method. This technique can reduce the internal stress generated during the sintering NC thin film and decrease defects. In the case of CdTe-CdS hetero-junction thin film solar cells, the thickness of the CdS has significant effects on the depletion field thickness, the built-in electric field, and the spectrum response for short wavelengths $(<500 \mathrm{~nm})$ of solar cells. Interdiffusion from $\mathrm{S}$ to CdTe is difficult in the solar cells, and photo-generated carriers 
produced by the CdS film cannot be separated effectively even if the $\mathrm{CdS}_{x} \mathrm{Te}_{1-x}$ transition layer is formed. At the same time, a device with a thin CdS thickness cannot form a strong built-in electric field, which will inhibit carrier separation and result in a low device performance. Therefore, the thickness of efficient CdTe-CdS thin film solar cells is about $100 \mathrm{~nm}$, based on previous results [15]. To investigate the thickness effects on device performance, devices with CdS thickness between 14.9 and $121 \mathrm{~nm}$ were fabricated by depositing one or more layers of CdS NC on the ITO/ZnO substrate with the same CdTe NCs film thickness $(\sim 400 \mathrm{~nm})$ and the same treatment conditions (annealing at $360^{\circ} \mathrm{C}$ ). Figure 4a presents the $J-V$ curves of CdTe/CdS NC solar cells with different CdS layer thicknesses under dark conditions. The dark current is almost always decreased with the increase of CdS thickness except for the thickest CdS layer where it again went up, which implied that thicker CdS film can effectively suppress leakage current. From the $J-V$ curves under light conditions (Figure $4 \mathrm{~b}$ ) and the data summarized in Table 1, the $V_{\mathrm{oc}}$ and PCE of the devices were improved almost linearly with the increased CdS thickness. The best device with $90.8 \mathrm{~nm} \mathrm{CdS}$ as the window layer exhibited a short circuit current density $\left(J_{\mathrm{sc}}\right)$ of $16.36 \mathrm{~mA} / \mathrm{cm}^{2}$, an open circuit voltage $\left(V_{\mathrm{oc}}\right)$ of $0.57 \mathrm{~V}$, a fill factor $(\mathrm{FF})$ of $42.74 \%$, and a high PCE of $3.98 \%$. In contrast, devices based on very thin CdS (14.9 nm) showed PCE of $1.87 \%, J_{\mathrm{sc}}$ of $12.14 \mathrm{~mA} / \mathrm{cm}^{2}, V_{\text {oc }}$ of $0.43 \mathrm{~V}$, and $\mathrm{FF}$ of $35.84 \%$. The low $\mathrm{FF}$ value was mainly due to the large carrier recombination that occurred in the interface of the $p-n$ junction. The PCE value of the best device was higher than the reported PCE values of devices made using CBD-CdS as the window layer reported in our previous work [35] and lower than that reported by crisp et al. [36]. It was noted that the $J_{\mathrm{sc}}$ is increased as the CdS thickness is increased and then was stable at around $16 \mathrm{~mA} / \mathrm{cm}^{2}$. From the external quantum efficiency spectrum (EQE, Solar Cell Scan100, Zolix Instruments Co., Ltd., Beijing, China), one can see that devices prepared with thin CdS film (less than $65 \mathrm{~nm}$ ) showed better response at short wavelength $(<500 \mathrm{~nm})$ than those devices with thick CdS film $(>70 \mathrm{~nm})$, which was mainly due to the decreased parasitic absorption.
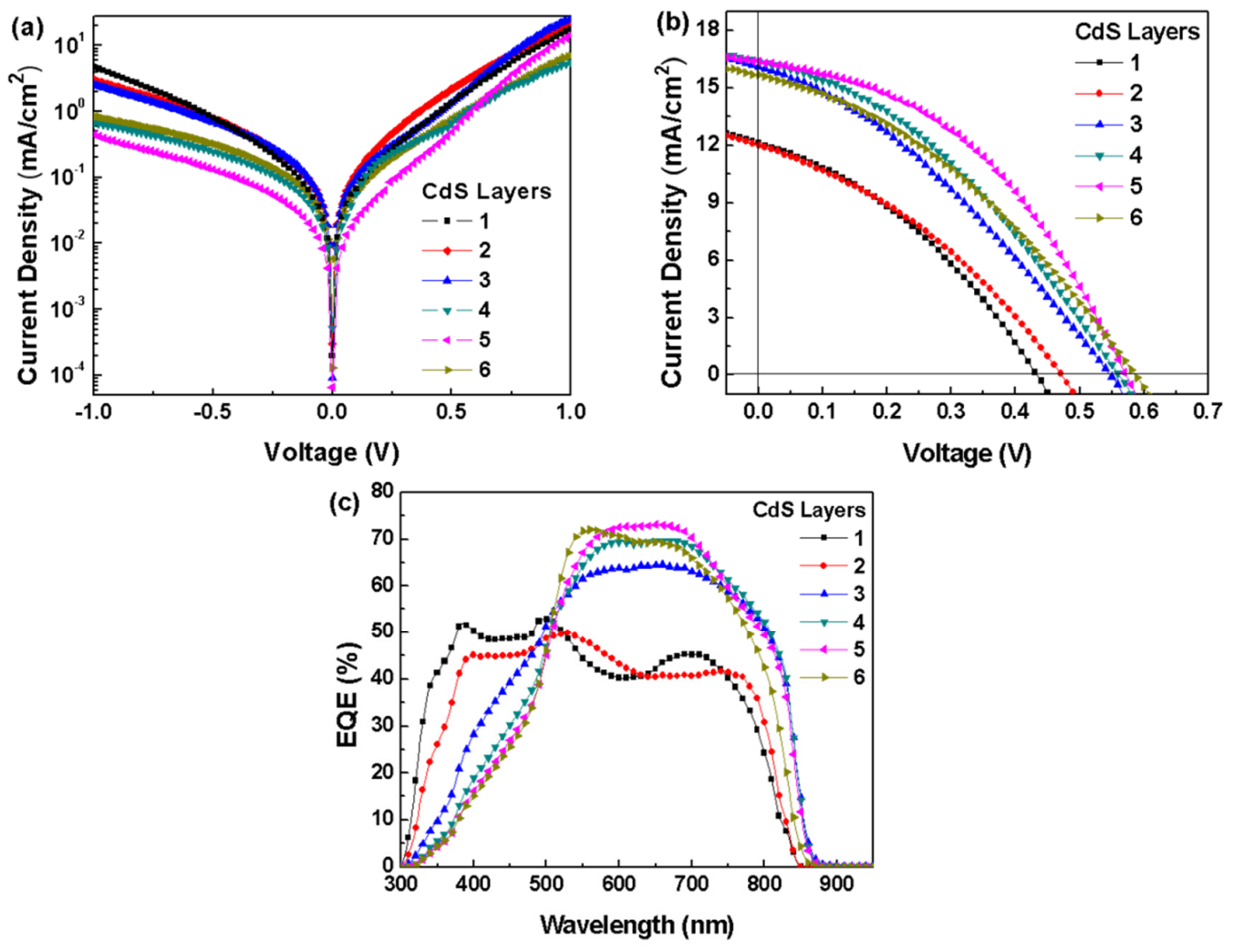

Figure 4. $J-V$ curves of CdTe/CdS NC solar cells with different CdS thickness (a) under dark and (b) under light; (c) EQE spectra of CdTe/CdS NC solar cells. 
Table 1. Summarized performance of CdTe/CdS NC solar cells with different CdS thicknesses (Figure 4b).

\begin{tabular}{cccccccc}
\hline CdS Layer & Thickness $(\mathbf{n m})$ & $\boldsymbol{V}_{\mathbf{o c}}(\mathbf{V})$ & $J_{\mathbf{s c}}\left(\mathbf{m A} / \mathbf{c m}^{2}\right)$ & FF (\%) & PCE $\mathbf{( \% )}$ & $\boldsymbol{R}_{\boldsymbol{s}} \mathbf{( \Omega \cdot \cdot \mathbf { c m } ^ { 2 } )}$ & $\boldsymbol{R}_{\text {sh }}\left(\boldsymbol{\Omega} \cdot \mathbf{c m}^{2}\right)$ \\
\hline 1 & 14.9 & 0.43 & 12.14 & 35.84 & 1.87 & 19.4 & 94.0 \\
2 & 41.0 & 0.47 & 11.98 & 34.79 & 1.96 & 21.7 & 88.0 \\
3 & 60.7 & 0.55 & 16.15 & 32.72 & 2.91 & 23.6 & 91.7 \\
4 & 76.3 & 0.56 & 16.39 & 36.28 & 3.33 & 21.4 & 138.0 \\
5 & 90.8 & 0.57 & 16.36 & 42.74 & 3.98 & 15.4 & 213.6 \\
6 & 124.1 & 0.59 & 15.66 & 35.40 & 3.27 & 22.3 & 136.9 \\
\hline
\end{tabular}

For CdTe-CdS hetero-junction solar cells, the quality of the hetero-junction is critical to the performance of the device. Since the lattice mismatch rate of CdS and CdTe is only $15 \%$, low device performances are likely to be obtained if the $\mathrm{CdTe} / \mathrm{CdS}$ junction is not treated effectively. Therefore, in order to activate the junction of $\mathrm{CdTe} / \mathrm{CdS}$, a layer of $\mathrm{CdCl}_{2}$ solution is usually deposited on the thin film and annealed at $\sim 400{ }^{\circ} \mathrm{C}$, which was done for CdTe/CdS solar cells prepared by the close-space sublimation (CSS) method [44-49]. As NC materials possess some unique physical properties, such as low melting point, easy processing, and easy doping, the optimized conditions for the treatment of NC thin film may be different from those of the bulk materials. In order to study the charge transport properties of CdS NC and annealing temperature, we fabricated electron-only devices with a structure of FTO/CdS ( $90 \mathrm{~nm}) / \mathrm{Al}(80 \mathrm{~nm})$ by depositing five layers of CdS NC on the FTO substrate. All alloy $\mathrm{NCs}$ thin films were annealed at different temperatures with $\mathrm{CdCl}_{2}$ treatment for $30 \mathrm{~min}$. The electron carrier mobility of the CdS NCs thin film was investigated by the space-charge-limited-current (SCLC) method. The carrier mobility was calculated according to the following equation [50]:

$$
J=\frac{9}{8} \frac{\varepsilon_{0} \varepsilon_{\mathrm{r}} \mu_{\mathrm{n}} V^{2}}{L^{3}}
$$

where $\varepsilon_{0}$ is the permittivity of free space, $\varepsilon_{\mathrm{r}}$ is the relative dielectric constant of CdS (here the value of $\varepsilon_{0} \varepsilon_{\mathrm{r}}$ is 9$), L$ is the thickness of the alloy NCs $(160 \mathrm{~nm}), \mu_{\mathrm{n}}$ is the electron mobility and $V$ is the applied voltage. By using a plot of we can calculate the mobility of CdS thin film based on the slope value obtained in this curve (also see Figure S1). As shown in Figure 5 and Table 2, the mobilities for annealing temperatures of $300,340,360,370,380$, and $400{ }^{\circ} \mathrm{C}$ were $3.87 \times 10^{-5}, 4.83 \times 10^{-5}$, $7.23 \times 10^{-5}, 1.29 \times 10^{-4}, 1.40 \times 10^{-4}$ and $6.05 \times 10^{-5} \mathrm{~cm}^{2} / \mathrm{V} \cdot \mathrm{s}$, respectively. It was obvious that the mobility almost linearly increased with the increase of annealing temperature from 300 to $380{ }^{\circ} \mathrm{C}$, then decreased with the further increase of temperature to $400{ }^{\circ} \mathrm{C}$. As all the samples were annealed under ambient conditions, the oxidation of $\mathrm{CdS}$ at high temperature will change the conductivity. When oxygen is intentionally incorporated into the CdS, it will increase the bandgap and conductivity of CdS, which has been confirmed in the literature [51,52]. In order to clarify the decrease in mobility of CdS NC thin film at high temperature, we measure the conductivity of ITO and ITO/ZnO substrate. From Table S1, one can see that the conductivity of ITO decreases linearly with the increase of annealing temperature. Therefore, higher temperatures lead to poorer ITO conductivity (the conductivity of ITO annealed at $400{ }^{\circ} \mathrm{C}$ is four times lower that at room temperature). On the contrary, as the $\mathrm{ZnO}$ thin film is prepared by annealing the $\mathrm{Zn}$ precursor at $400{ }^{\circ} \mathrm{C}$ for $10 \mathrm{~min}$, the conductivity shows almost no changes when further annealing at $340-400^{\circ} \mathrm{C}$. Therefore, we speculate that when CdS NC thin film is annealed at a high temperature of $400{ }^{\circ} \mathrm{C}$, it will result in poorer ITO conductivity, and the mobility of the CdS NC thin film is likely to decrease.

To investigate the annealing effects on the performance of NC solar cells, we fabricated solar cells with different annealing temperatures ranging from 300 to $400{ }^{\circ} \mathrm{C}$. For comparison, a device with CBD-CdS as the window layer was also fabricated. The $J-V$ curves of the materials with different annealing temperatures under dark/light conditions were presented in Figure $6 \mathrm{a}, \mathrm{b}$. From the $J-V$ under dark conditions, there were large leakage current and bad diode property at the low annealing temperature of $300{ }^{\circ} \mathrm{C}$, which implies that the interface of the hetero-junction contained a lot of 
defects. In contrast, the leakage current was suppressed dramatically when the annealing temperature was above $340{ }^{\circ} \mathrm{C}$. The device annealing at $380^{\circ} \mathrm{C}$ showed the lowest leakage current and the best diode properties.
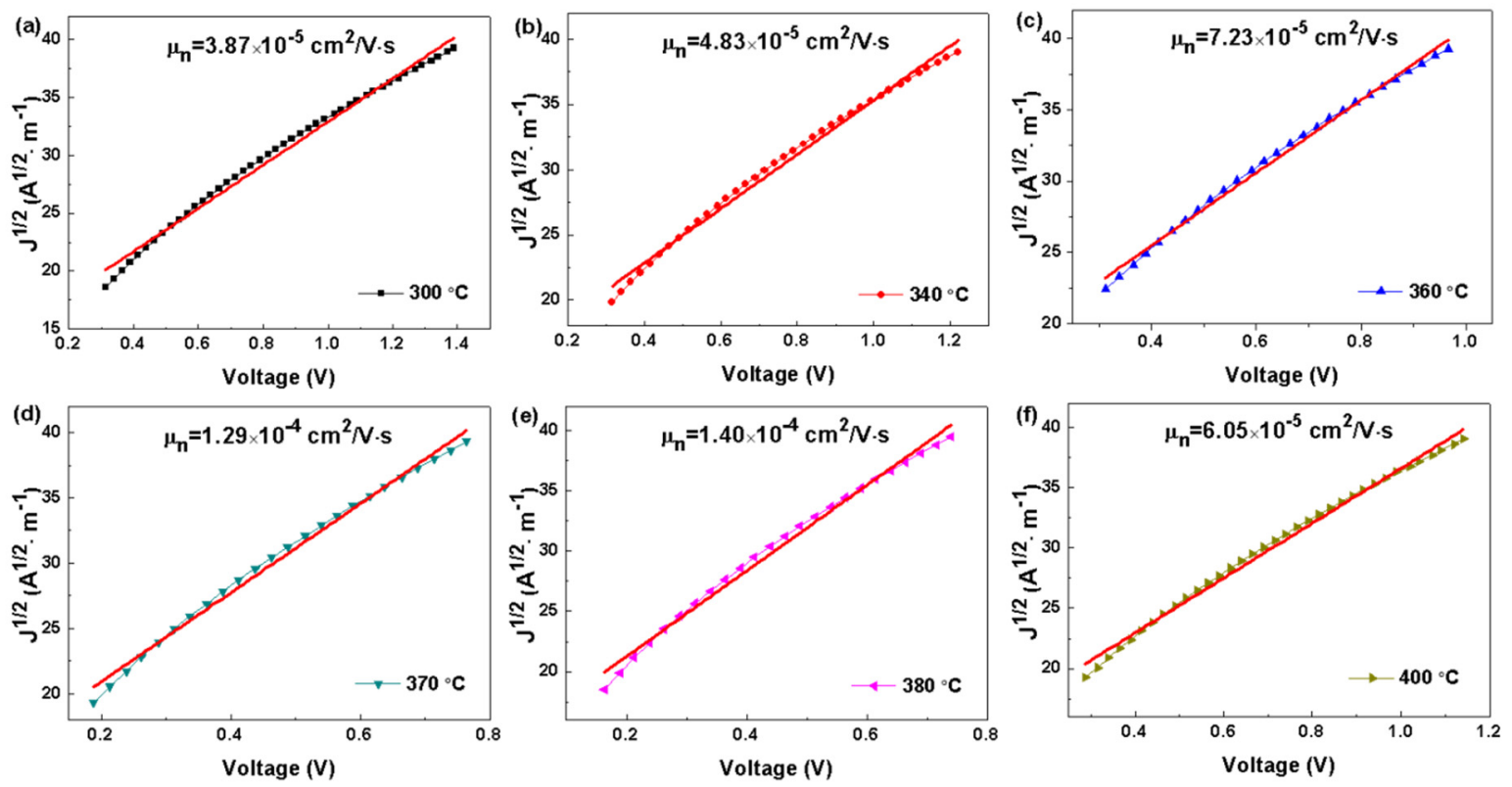

Figure 5. Linearly fitting SCLC measurements of CdS NC thin films under different annealing temperatures: (a) $300{ }^{\circ} \mathrm{C}$; (b) $340{ }^{\circ} \mathrm{C}$; (c) $360{ }^{\circ} \mathrm{C}$; (d) $370{ }^{\circ} \mathrm{C}$; (e) $380{ }^{\circ} \mathrm{C}$; (f) $400{ }^{\circ} \mathrm{C}$. $\varepsilon_{0}=8.85 \times 10^{-12}$, $\varepsilon_{\mathrm{r}}=9, L=160 \mathrm{~nm}$.

Table 2. Summarized electron mobility of CdS NC thin films with different annealing temperature (Figure 5).

\begin{tabular}{|c|c|}
\hline Annealing Temperature & Hole Mobility $\left(\mathrm{cm}^{2} \cdot \mathrm{V}^{-1} \cdot \mathrm{s}^{-1}\right)$ \\
\hline $300^{\circ} \mathrm{C}$ & $3.87 \times 10^{-5}$ \\
\hline $340^{\circ} \mathrm{C}$ & $4.83 \times 10^{-5}$ \\
\hline $360^{\circ} \mathrm{C}$ & $7.23 \times 10^{-5}$ \\
\hline $370^{\circ} \mathrm{C}$ & $1.29 \times 10^{-4}$ \\
\hline $380^{\circ} \mathrm{C}$ & $1.40 \times 10^{-4}$ \\
\hline $400^{\circ} \mathrm{C}$ & $6.05 \times 10^{-5}$ \\
\hline
\end{tabular}

From the $J-V$ curves under dark conditions (Figure $6 \mathrm{~b}$ ) and Table 3, we can see that device annealing at the moderate temperature of $370{ }^{\circ} \mathrm{C}$ showed the highest $V_{\mathrm{oc}}$ of $0.59 \mathrm{~V}$ coupled with a high PCE of $4.69 \%$. With the further increase of the annealing temperature to $380{ }^{\circ} \mathrm{C}$, we obtained a device with the best properties: $V_{\mathrm{oc}}=0.56 \mathrm{~V}, J_{\mathrm{sc}}=17.26 \mathrm{~mA} / \mathrm{cm}^{2}, \mathrm{FF}=52.84 \%$, and $\mathrm{PCE}=5.14 \%$. We speculated that at this annealing temperature, the carrier mobility was high (see Figure 5), which promotes carrier departure and transfer, resulting in a high $J_{\mathrm{sc}}$ value in this case. Additionally, the diffusion of $\mathrm{S}$ and $\mathrm{Te}$ at this temperature will partly eliminate interface defects for improved device performance. On the contrary, the $V_{\mathrm{oc}}, J_{\mathrm{sc}}, \mathrm{FF}$, and PCE values for the device prepared with CBD-CdS as the window layer were determined as $0.52 \mathrm{~V}, 17.36 \mathrm{~mA} / \mathrm{cm}^{2}, 48.6 \%$, and $3.61 \%$ respectively (Figure $6 \mathrm{c}$ ). The PCE value of our best performing devices was $35 \%-60 \%$ higher than those of conventional solution-processed $\mathrm{CdTe} / \mathrm{CdS}$ solar cells using CBD-CdS as the window layer. Compared to the device with CBD-CdS, the device based on CdS NC showed higher $V_{\text {oc }}$ and FF, but similar $J_{\text {sc }}\left(\sim 17 \mathrm{~mA} / \mathrm{cm}^{2}\right)$. Therefore, the increase in the PCE of CdTe NC solar cells with CdS NC as the window layer is mainly attributed to the high junction quality and low interface defects. The decrease in device performance at high annealing temperatures was likely due to the oxidation of NC at high temperature as the device was 
fabricated at ambient conditions. From the EQE spectra presented in Figure 6d, one can see that devices produced at annealing temperatures below $370{ }^{\circ} \mathrm{C}$ showed inferior response at wavelengths between 300 to $500 \mathrm{~nm}$, but significant increased response in this region was observed for devices subjected to higher annealing temperatures of $380^{\circ} \mathrm{C}$ and $400{ }^{\circ} \mathrm{C}$. We speculate that at high annealing temperatures, the diffusion of $\mathrm{S}$ and Te resulted in the formation of a homogeneous $\mathrm{CdS}_{x} \mathrm{Te}_{1-x}$ alloy and reduced the parasitic absorption due to the decreased thickness of the CdS layer.
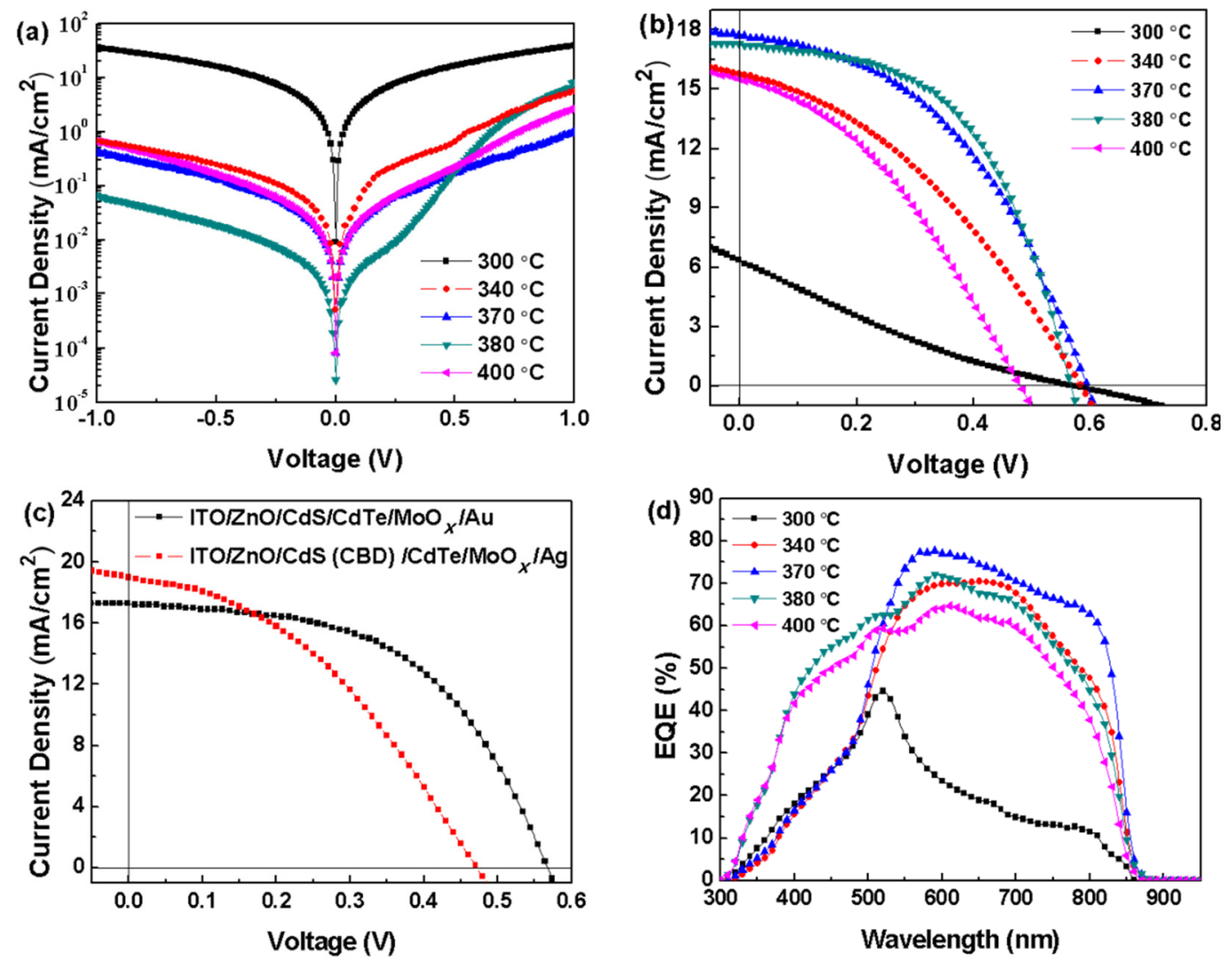

Figure 6. $J-V$ curves of $C \mathrm{dTe} / \mathrm{CdS} \mathrm{NC}$ solar cells with different annealing temperatures (a) under dark and (b) under light; (c) the comparison of CdTe/CdS solar cells with CBD-CdS or CdS NCs as window layers; and (d) the resultant EQE spectra.

Table 3. Summarized performance of CdTe/CdS NC solar cells with different annealing temperatures (Figure 6).

\begin{tabular}{cccccc}
\hline CdS Film & Annealing Temperature & $V_{\mathbf{o c}}(\mathbf{V})$ & $J_{\mathbf{s c}}\left(\mathbf{m A} / \mathbf{c m}^{\mathbf{2}}\right)$ & FF (\%) & PCE (\%) \\
\hline NC & $300^{\circ} \mathrm{C}$ & 0.57 & 6.36 & 19.73 & 0.72 \\
NC & $340^{\circ} \mathrm{C}$ & 0.59 & 15.79 & 36.45 & 3.40 \\
NC & $370^{\circ} \mathrm{C}$ & 0.59 & 17.69 & 44.63 & 4.69 \\
NC & $380^{\circ} \mathrm{C}$ & 0.56 & 17.26 & 52.84 & 5.14 \\
NC & $400^{\circ} \mathrm{C}$ & 0.48 & 15.54 & 36.39 & 2.74 \\
CBD & $380^{\circ} \mathrm{C}$ & 0.52 & 17.36 & 48.60 & 3.61 \\
\hline
\end{tabular}

\section{Conclusions}

In summary, we described a new semiconductor material, CdS NCs, for application in solution-processed NC solar cells. Devices with an inverted structure of ITO/ZnO/CdS/CdTe/ $\mathrm{MoO}_{x} / \mathrm{Au}$ were fabricated using a layer-by-layer sintering technique. The device performance can be tailored by adjusting the thickness of the CdS NC film and the annealing temperature. We confirmed that that device 
containing a thin film of CdS NCs as the window layer showed better diode properties than that with $\mathrm{CBD}-\mathrm{CdS}$ as the window layer. By carefully optimizing the processing parameters (annealing temperature and film thickness), we obtained a superior device with a PCE of $5.14 \%$, which is $35 \%$ higher than that of previously reported devices. Our results suggest that significant improvement in the performance of $\mathrm{CdTe} / \mathrm{CdS}$ NC solar cells is possible if the CdS film is subjected to a more optimized level of processing.

Supplementary Materials: The following are available online at http:/ / www.mdpi.com/2079-6412/8/1/26/s1, Figure S1: $J^{1 / 2} \propto V$ curves of CdS NC thin film at different annealing temperatures; Table S1: Conductivity of ITO and ITO $/ \mathrm{ZnO}$ at different annealing temperatures.

Acknowledgments: We thank the financial support of the National Natural Science Foundation of China (Nos. 91333206, 61774077 and 61274062), National Science Foundation for Distinguished Young Scholars of China (Grant No. 51225301), Guangdong Province Natural Science Fund (Nos. 2014A030313257) and National Undergraduate Innovative and Entrepreneurial Training Program (No. 201710561048).

Author Contributions: Songwei Liu and Donghuan Qin conceived and designed the experiments; Songwei Liu, Weigeng Liu, Jingxuan Heng, Wenfeng Zhou, Yanru Chen and Shiya Wen performed the experiments; Songwei Liu, Lintao Hou and Dan Wang analyzed the data; Hui Xu contributed reagents/materials/analysis tools; Songwei Liu, Lintao Hou and Donghuan Qin wrote the paper.

Conflicts of Interest: The authors declare no conflict of interest.

\section{References}

1. Kim, J.Y.; Voznyy, O.; Zhitomirsky, D.; Sargent, E.H. Colloidal quantum dot materials and devices: A quarter-century of advances. Adv. Mater. 2013, 25, 4986-5010. [CrossRef] [PubMed]

2. Kagan, C.R.; Lifshitz, E.; Sargent, E.H.; Talapin, D.V. Building devices from colloidal quantum dots. Science 2016, 353, aac5523. [CrossRef] [PubMed]

3. Xue, H.; Wu, R.; Xie, Y.; Tan, Q.; Qin, D.; Wu, H.; Huang, W. Recent progress on solution-processed CdTe nanocrystals solar cells. Appl. Sci. 2016, 6, 197. [CrossRef]

4. Chen, G.; Ning, Z.; Agren, H. Nanostructured Solar Cells. Nanomaterials 2016, 6, 145. [CrossRef] [PubMed]

5. Paulo, S.; Palomares, E.; Martinez-Ferrero, E. Graphene and carbon quantum dot-based materials in photovoltaic devices: From synthesis to applications. Nanomaterials 2016, 6, 157. [CrossRef] [PubMed]

6. Maloney, F.S.; Poudyal, U.; Chen, W.; Wang, W. Influence of quantum dot concentration on carrier transport

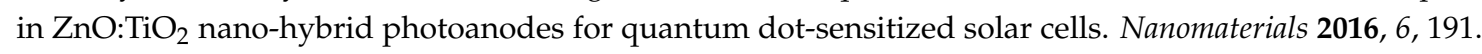
[CrossRef] [PubMed]

7. Wu, R.; Yang, Y.; Li, M.; Qin, D.; Zhang, Y.; Hou, L. Solvent engineering for high-performance PbS quantum dote solar cells. Nanomaterials 2017, 7, 201. [CrossRef] [PubMed]

8. Yang, Y.; Zhao, B.; Gao, Y.; Liu, H.; Tian, Y.; Qin, D.; Wu, H.; Huang, W.; Hou, L. Novel hybrid ligands for passivating $\mathrm{PbS}$ colloidal quantum dots to enhance the performance solar cells. Nano-Micro Lett. 2015, 7, 325-331. [CrossRef]

9. Wu, H.; Zhang, X.; Zhang, Y.; Yan, L.; Gao, W.; Zhang, T.; Wang, Y.; Zhao, J.; Yu, W.W. Colloidal PbSe Solar Cells with Molybdenum Oxide Modified Graphene Anodes. ACS Appl. Mater. Interfaces 2015, 7, 21082-21088. [CrossRef] [PubMed]

10. Zhu, J.; Yang, Y.; Gao, Y.; Qin, D.; Wu, H.; Hou, L.; Huang, W. Enhancement of open-circuit voltage and the fill factor in CdTe nanocrystal solar cells by using inferface materials. Nanotechnology 2014, 25, 365203. [CrossRef] [PubMed]

11. Li, M.; Liu, X.; Wen, S.; Liu, S.; Heng, J.; Qin, D.; Hou, L.; Wu, H.; Xu, W.; Huang, W. CdTe Nanocrystal Hetero-Junction Solar Cells with High Open Circuit Voltage Based on Sb-doped $\mathrm{TiO}_{2}$ Electron Acceptor Materials. Nanomaterials 2017, 7, 101. [CrossRef] [PubMed]

12. Dharmadasa, I.M.; Madugu, M.L.; Olusola, O.I.; Echendu, O.K.; Fauzi, F.; Diso, D.G.; Weerasinghe, A.R.; Druffel, T.; Dharmadasa, R.; Lavery, B.; et al. Electroplating of CdTe thin films from cadmium sulphate precursor and comparison of layers grown by 3-electrode and 2-electrode systems. Coatings 2017, 7, 17. [CrossRef]

13. Kim, K.; Eo, Y.J.; Cho, A.; Gwak, J.; Yun, J.H.; Shin, K.; Ahn, S.K.; Park, S.H.; Yoon, K.; Ahn, S. Role of chelate complexes in densification of $\mathrm{CuInSe}_{2}$ (CIS) thin film prepared from amorphous Cu-In-Se nanoparticle precursors. J. Mater. Chem. 2012, 22, 8444-8448. [CrossRef] 
14. Hahn, J.S.; Park, G.; Lee, J.; Shim, J. Synthesis of CuInSe 2 nanoparticles in an oleic acid solution for application in thin film solar cells. J. Ind. Eng. Chem. 2015, 21, 754-759. [CrossRef]

15. Britt, J.; Ferekides, C. Thin-film CdS/CdTe solar cell with $15.8 \%$ efficiency. Appl. Phys. Lett. 1993, 62, 2851-2852. [CrossRef]

16. Dharmadasa, I.M.; Ojo, A.A.; Salim, H.I.; Dharmadasa, R. Next generation solar cells based on graded bandgap device structures utilizing rod-type nano-materials. Energies 2015, 8, 5440-5458. [CrossRef]

17. Acharya, S.; Bangera, K.V.; Shivakumar, G.K. Electrical characterization of vacuum-deposited $p$-CdTe $/ n-Z n S e$ heterojunctions. Appl. Nanosci. 2015, 5, 1003-1007. [CrossRef]

18. Liu, B.; Luo, R.; Liang, Q.; Zheng, Y.; Li, B.; Zhang, J.; Li, W.; Wu, L.; Feng, L. Preparation of novel CdS/ZnS composite window layer for CdTe thin film solar cell. J. Mater. Sci. Mater. Electron. 2015, 26, 9985-9990. [CrossRef]

19. Horsley, K.; Beal, R.J.; Wilks, R.G.; Blum, M.; Häming, M.; Hanks, D.A.; Weir, M.G.; Hofmann, T.; Weinhardt, L.; Bär, M.; et al. Impact of annealing on the chemical structure and morphology of the thin-film CdTe/ZnO interface. J. Appl. Phys. 2014, 116, 024312. [CrossRef]

20. Green, M.A.; Emery, K.; Hishikawa, Y.; Warta, W.; Dunlop, E.D.; Levi, D.H.; Ho-Baillie, A.W.Y. Solar cell efficiency tables (version 49). Prog. Photovolt. Res. Appl. 2017, 25, 3-13. [CrossRef]

21. Burst, J.M.; Duenow, J.N.; Albin, D.S.; Colegrove, E.; Reese, M.O.; Aguiar, J.A.; Jiang, C.-S.; Patel, M.K.; Al-Jassim, M.M.; Kuciauskas, D.; et al. CdTe solar cells with open-circuit voltage breaking the $1 \mathrm{~V}$ barrier. Nat. Energy 2016, 15, 16051. [CrossRef]

22. Gur, I.; Fromer, N.A.; Geier, M.L.; Alivisators, A.P. Air-stable all-inorganic nanocrystal solar cells processed from solution. Science 2005, 310, 462-465. [CrossRef] [PubMed]

23. Xie, Y.; Tan, Q.; Zhang, Z.; Lu, K.; Li, M.; Xu, W.; Qin, D.; Zhang, Y.; Hou, L.; Wu, H. Improving performance in CdTe/CdSe nanocrystal solar cells by using bulk nano-heterojunctions. J. Mater. Chem. C 2016, 4, 6483-6491. [CrossRef]

24. Liu, H.; Tian, Y.; Zhang, Y.; Gao, K.; Lu, K.; Wu, R.; Qin, D.; Wu, H.; Peng, Z.; Hou, L.; et al. Solution processed $\mathrm{CdTe} / \mathrm{CdSe}$ nanocrystal solar cells with more than $5.5 \%$ efficiency by using an inverted device structure. J. Mater. Chem. C 2015, 3, 4227-4234. [CrossRef]

25. Anderson, I.E.; Breeze, A.J.; Olson, J.D.; Yang, L.; Sahoo, Y.; Carter, S.A. All-inorganic spin-cast nanoparticle solar cells with nonselective electrodes. Appl. Phys. Lett. 2009, 94, 063101. [CrossRef]

26. Wen, S.; Li, M.; Yang, J.; Mei, X.; Wu, B.; Liu, X.; Heng, J.; Qin, D.; Hou, L.; Xu, W.; et al. Rationally controlled synthesis of $\mathrm{CdSe}_{x} \mathrm{Te}_{1-x}$ alloy nanocrystals and their application in efficient graded bandgap solar cells. Nanomaterials 2017, 7, 380. [CrossRef] [PubMed]

27. MacDonald, B.I.; Martucci, A.; Rubanov, S.; Wakins, S.E.; Mulvaney, P.; Jasieniak, J.J. Layer-by-layer assembly of sintered CdSe $\mathrm{Te}_{1-x}$ nanocrystal solar cells. ACS Nano 2012, 6, 5995-6004. [CrossRef] [PubMed]

28. Jasieniak, J.; MacDonald, B.I.; Wakins, S.E.; Mulvaney, P. Solution-processed Sintered Nanocrystal Solar Cells via Layer-by-Layer Assembly. Nano Lett. 2011, 11, 2856-2864. [CrossRef] [PubMed]

29. Kumar, S.G.; Rao, K.S.R.K. Physics and chemistry of CdTe/CdS thin film heterojunction photovoltaic devices: Fundamental and critical aspects. Energy Environ. Sci. 2014, 7, 45-102. [CrossRef]

30. Zhang, H.; Kurley, J.M.; Russell, J.C.; Jang, J.; Talapin, D.V. Solution-processed, ultrathin solar cells from $\mathrm{CdCl}_{3}{ }^{-}$-capped CdTe nanocrystals: The multiple roles of $\mathrm{CdCl}_{3}{ }^{-}$ligands. J. Am. Chem. Soc. 2016, 138, 7464-7467. [CrossRef] [PubMed]

31. Panthani, M.G.; Kurley, J.M.; Crisp, R.W.; Dietz, T.C.; Ezzyat, T.; Luther, J.M.; Talapin, D.V. High efficiency solution processed sintered CdTe nanocrystal solar cells: The role of interfaces. Nano Lett. 2014, 14, 670-675. [CrossRef] [PubMed]

32. Macdonald, B.I.; Gengenbach, T.R.; Watkins, S.E.; Mulvaney, P.; Jasieniak, J.J. Solution-processing of ultra-thin CdTe/ZnO nanocrystal solar cells. Thin Solid Films 2014, 558, 365-373. [CrossRef]

33. Chen, Z.; Zhang, H.; Zen, Q.; Wang, Y.; Xu, D.; Wang, L.; Wang, H.; Yang, B. In Situ Construction of nanoscale CdTe-CdS bulk heterojunctions for inorganic nanocrystal solar cells. Adv. Energy Mater. 2014, 4, 1400235. [CrossRef]

34. Chen, Z.; Zeng, Q.; Liu, F.; Jin, G.; Du, X.; Du, J.; Zhang, H.; Yang, B. Efficient inorganic solar cells from aqueous nanocrystals: The impact of composition on carrier dynamics. RSC Adv. 2015, 5, 74263-74269. [CrossRef] 
35. Tian, Y.; Zhang, Y.; Lin, Y.; Gao, K.; Zhang, Y.; Liu, K.; Yang, Q.; Zhou, X.; Qin, D.; Wu, H.; et al. Solution-processed efficient CdTe nanocrystal/CBD-CdS hetero-junction solar cells with ZnO interlayer. J. Nanopart. Res. 2013, 15, 2053. [CrossRef]

36. Crisp, R.W.; Panthani, M.G.; Rance, W.L.; Duenow, J.N.; Parilla, P.A.; Callahan, R.; Dabney, M.S.; Berry, J.J.; Talapin, D.V.; Luther, J.M. Nanocrystal grain growth and device architectures for high-efficiency CdTe ink-based photovoltaics. ACS Nano 2014, 8, 9063-9072. [CrossRef] [PubMed]

37. Crisp, R.W.; Pach, G.F.; Kurley, J.M.; France, R.M.; Reese, M.O.; Nanayakkara, S.U.; Macleod, B.A.; Talapin, D.V.; Beard, M.C.; Luther, J.M. Tandem solar cells from solution-processed CdTe and PbS quantum dots using a ZnTe-ZnO tunnel junction. Nano Lett. 2017, 17, 1020-1027. [CrossRef] [PubMed]

38. Cao, Y.; Wang, J. One-pot Synthesis of high-quality zinc-blende CdS nanocrystals. J. Am. Chem. Soc. 2004, 126, 14336-14337. [CrossRef] [PubMed]

39. Peng, Z.A.; Peng, X. Formation of high-quality CdTe, CdSe, and CdS nanocrystals using CdO as precurssor. J. Am. Chem. Soc. 2001, 123, 183-184. [CrossRef] [PubMed]

40. Li, Z.; Ji, Y.; Xie, R.; Grisham, S.Y.; Peng, X. Correlation of CdS Nanocrystal Formation with Elemental Sulfur Activation and Its Implication in Synthetic Development. J. Am. Chem. Soc. 2011, 133, 17248-17256. [CrossRef] [PubMed]

41. Yong, K.; Sahoo, Y.; Swihart, M.T.; Prasad, P.N. Shape control of CdS nanocrystals in one-pot synthesis. J. Phys. Chem. C 2007, 111, 271-273. [CrossRef]

42. Chu, H.; Li, X.; Chen, G.; Zhou, W.; Zhang, Y.; Jin, Z.; Xu, J.; Li, Y. Shape-controlled synthesis of CdS nanocrystals in mixed solvents. Cryst. Growth Des. 2005, 5, 1801-1806. [CrossRef]

43. Yu, W.; Peng, X. Formation of high-quality CdS and other II-VI semiconductor nanocrystals in noncoordinating solvents: Tunable reactivity of monomers. Angew. Chem. Int. Ed. 2002, 41, 2368-2371. [CrossRef]

44. Duffy, N.W.; Peter, L.M.; Wang, R.L. Characterisation of CdS/CdTe heterojunctions by photocurrent spectroscopy and electroreflectance/absorbance spectroscopy (EEA/EER). J. Electroanal. Chem. 2002, 532, 207-214. [CrossRef]

45. Han, J.; Liao, C.; Jiang, T.; Spanheimer, C.; Haindl, G.; Fu, G.; Krishnakumar, V.; Zhao, K.; Klein, A.; Jaegermann, W. An optimized multilayer structure of CdS layer for CdTe solar cells application. J. Alloys Compd. 2011, 509, 5285-5289. [CrossRef]

46. Lin, H.; Xia, W.; Wu, H.; Tang, C. CdS/CdTe solar cells with $\mathrm{MoO}_{x}$ as back contact buffers. Appl. Phys. Lett. 2010, 97, 123504. [CrossRef]

47. Yun, J.H.; Cha, E.S.; Ahn, B.T.; Kwon, H.; Al-Ammar, E.A. Performance improvement in CdTe solar cells by modifying the CdS/CdTe interface with a Cd treatment. Curr. Appl. Phys. 2014, 14, 630-635. [CrossRef]

48. Xiao, D.; Li, X.; Wang, D.; Li, Q.; Shen, K.; Wang, D. CdTe thin film solar cell with NiO as a back contact buffer layer. Sol. Energy Mater. Sol. Cells 2017, 169, 61-67. [CrossRef]

49. Spalatu, N.; Hiie, J.; Mikli, V.; Krunks, M.; Valdna, V.; Maticiuc, N.; Raadik, T.; Caraman, M. Effect of CdCl $\mathrm{Cl}_{2}$ annealing treatment on structural and optoelectronic properties of close spaced sublimation $\mathrm{CdTe} / \mathrm{CdS}$ thin film solar cells vs deposition conditions. Thin Solid Films 2015, 582, 128-133. [CrossRef]

50. Chu, T.-Y.; Song, O.-K. Hole mobility of $N, N^{\prime}$-bis(naphthalen-1-yl)- $N, N^{\prime}$-bis(phenyl) benzidine investigated by using space-charge-limited currents. Appl. Phys. Lett. 2007, 90, 203512. [CrossRef]

51. Meysing, D.M.; Wolden, C.A.; Griffith, M.M.; Mahabaduge, H.; Pankow, J.; Reese, M.O.; Burst, J.M.; Rance, W.L.; Barnes, T.M. Properties of Reactively Sputtered Oxygenated Cadmium Sulfide (CdS:O) and Their Impact on CdTe Solar Cell Performance. J. Vac. Sci. Technol. A Vac. Surf. Films 2015, 33, 021203. [CrossRef]

52. Varkey, A.J.; Fort, A.F. Transparent conducting cadmium oxide thin films prepared by a solution growth technique. Thin Solid Films 1994, 239, 211-213. [CrossRef]

(C) 2018 by the authors. Licensee MDPI, Basel, Switzerland. This article is an open access article distributed under the terms and conditions of the Creative Commons Attribution (CC BY) license (http://creativecommons.org/licenses/by/4.0/). 